$\underline{\text { Editorial }}$

\title{
Role of Farm Animals and Its Contribution to Ecosystems
}

\author{
W.A.D. Nayananjalie
}

Editor,

Sri Lankan Journal of Agriculture and Ecosystems, Faculty of Agriculture, Rajarata University of Sri Lanka.

\section{Correspondence:
deepthin@agri.rjt.ac.lk}

(iD) https://orcid.org/0000-0002-5225-0074

DOI: http://doi.org/10.4038/sljae.v3i1.56

\begin{abstract}
Assurance of food security is vital in addressing many prevailing challenges in the world. Livestock plays a significant role in providing food products and many more services for humans and ecosystems. In this note, the importance of farm animals for better nutrition and for valuable contributions to ecosystem sustainability is discussed. The population of the world is growing at a rate of $2 \%$ per year which is the fastest in the history. The application of agricultural innovations and enhanced food production should be ensured to meet the requirement of exploding population. Crop production ensures food security in many instances. Similarly, the role of farm animals in food security is also important. Livestock plays a significant role in the ecosystems and. Livestock transforms feed into nutritious food, and useful products and interacts directly with ecosystems through grazing and the production of dung and urine. Thereby, it maintains the environment by recycling in the mixed farming system. Thus, farm animals actively play a key role in integrated sustainable farming systems creating an eco-friendly environment. Farm animals contribute to direct food production and to multiple uses such as fertilizer, fuel, capital accumulation and other by-products. Further, farm animals provide economic diversification and risk distribution which reduce income variability and provide renewable energy for agriculture in developing countries. However, ecosystem services provided by livestock species and the consequences of different management practices of livestock farming are yet to be well understood.
\end{abstract}

This is an open-access article distributed under the terms of the Creative Commons Attribution 4.0 International License, which permits unrestricted use, distribution and reproduction in any medium provided the original author and source are credited. 
Food security is defined as access to sufficient, safe, nutritious food to maintain a healthy and active life (United Nations 1975), and is one of the main global challenges of the $21^{\text {st }}$ century. Many challenges are associated with feeding the world with rapidly growing population. Limited availability of arable land and clean water resources, climate change, dietary shift, livestock and human health are some of the challenges, the world is facing today. It is predicted that the human population will be increased by $33 \%$ in 2050 and this would require an increase of overall food production by 70\% (FAO 2009). Therefore, this challenge is only possible through the application of agricultural innovations and enhanced efficiency of food production.

Similar to crop production, the role of farm animals in food security is important because livestock plays a significant role in the ecosystems. They are the most positive contributors in many agro-ecosystems transforming feed into nutritious food and useful products. Cattle convert grass into milk and meat; interact directly with ecosystems through grazing and the production of dung and urine. Poultry are also vital for human nutrition because it provides meat and eggs in food security and contributing to mixed farming practices and women empowerment (Wong et al, 2017). In order to fulfill the demand for animal products to feed the human population in the next few decades, the livestock industry has a massive role to play. However, with the increasing demand for food and other basic needs of humans, the ecosystems are highly threatened and imbalanced. Quick attention and practical measures are highly required to safeguard the ecosystems.

Livestock species have been domesticated, selected and bred over the years, creating a range of breeds with specific traits. These breeds are adapted to specific environments, for the conversion of particular types of vegetation into food, or for the production of specific products. High producers are intensively bred to supply uniform products under an intensive management system. Small-scale farmers mainly keep multipurpose breeds in low input production systems. Most of the farm animals actively contribute to integrated sustainable farming systems.

Milk, meat, eggs, dairy products and edible offal supply essential protein, vitamins and other micronutrients. Milk in the diet can tremendously be important for eliminating malnutrition and ensuring healthy development in children. Certainly, animal products are the best sources of quality protein with high bioavailability. Further, they are rich in many deficient micronutrients such as iron, zinc, and 
vitamins B-12 and A (McAfee, 2010; Randolph, 2007). Since farm animals are recognized as quality foods, demand for animal products continues to increase. Specially, chicken meat and eggs are the best sources of protein that can be afforded by the majority of people. In developing countries, the diet of people living in cities usually contains more animal protein than that of rural people mainly because they generally have access to a wider variety of foods at local markets. In low-income countries, chicken meat is well placed to satisfy the demands of the middle class who can afford to pay for meat of broiler chickens (Muchenje et al. 2018).

Small scale farmers contribute to food production and play a significant role in minimizing food insecurity, especially among poor rural household. Farm animals are a component of their farming systems and contribute not only to the direct food production but also include multiple uses such as fertilizer, fuel, capital accumulation and other by-products. Furthermore, farm animals are closely associated with the social and cultural lives of many people. Farm animals provide economic diversification and risk distribution which reduce income variability. In marginal environments where crop production is limited, well-adapted breeds can be reared which enhances the land-use efficiency.

Farm animals provide renewable energy for agriculture in developing countries. The use of draught animal power in land preparation, weeding and harvesting improves the soil structure and thereby conserves the soil. Farm animals play a key role in the integration of nutrients into the soil. Ruminants, who graze on the pasture, and are fed with crop residues and byproducts yield manure to the soil. Poultry manure is also rich in many nutrients which can be used to fertilize the crops. Livestock can be used to control the weeds in agricultural lands especially in plantation crops. They are currently being used in plantations of coconut, rubber, mango, and sugarcane. While grazing most commonly; cattle, goat and sheep add manure as organic fertilizer to grazing lands.

Ecosystem services of livestock species and the consequences of different management practices of livestock farming are yet to be well understood. As the livestock population is increasing, it contributes to contamination of groundwater, eutrophication and soil pollution. In addition, livestock farming produces significant quantities of "greenhouse gases", thereby contributing to global warming. Interactions between livestock management 
and the ecosystem functions should be further investigated to support experts and livestock keepers to choose the best management practices. Therefore, suitable mechanisms are vital to be introduced to conserve and maintain the ecosystem in a sustainable manner.

\section{References}

FAO (2009) FAO's Director-General on How to Feed the World in 2050. Population and Development Review. 35(4): 837-839. Available at:http://www.jstor. org/stable/ 25593700 (Accessed 2nd June 2021).

McAfee A J, McSorley E M, Cuskelly G J, Moss B W, Wallace J M W, Bonham M P, Fearon A M (2010) Red meat consumption: an overview of the risks and benefits. Meat Sci, 84: 1-13.

Muchenje V, Mukumbo F E, Descalzo A M, Schonfeldt H C (2018) Introduction to the special issue on balanced diets in food systems: emerging trends and challenges for human health and wellbeing. The Open Agric J, 5(1): 30-3.
Randolph T F, Schelling E, Grace D, Nicholson C F, Leroy J L, Cole D C, Demment M W, Omore A, Zinsstag J, Ruel M (2007) Invited review: role of livestock in human nutrition and health for poverty reduction in developing countries. J Anim Sci, 85: 2788800.

United Nations (1975) Report of the World Food Conference, Rome 5-16 November 1974. New York, USA.

Wong J T, de Bruyn J, Bagnol B, Grieve H, Pym M Li R, Alders R G (2017) Small-scale poultry and food security in resource-poor settings: A review, Global Food Security, 15: 43-52. 